\title{
Compressive strength of glass ionomer cements using different specimen dimensions
}

\author{
Resistência à compressão de cimentos de \\ ionômero de vidro utilizando-se diferentes \\ tamanhos de corpos-de-prova
}

\section{André Mallmann (a) Jane Clei Oliveira Ataíde ${ }^{(b)}$ Rosa Amoedo(a) Paulo Vicente Rocha(c) Letícia Borges Jacques(d)}

\section{(a) Assistant Professors, School of Dentistry, Foundation for Science Development, Salvador. \\ (b)DDS; (c)Chair and professor - Department of Health, School of Dentistry, State University of Feira de Santana. \\ (d) Assistant Professor, Department of Restorative Dentistry, School of Dentistry, Federal University of Santa Maria.}

\begin{abstract}
The purpose of this study was to evaluate the compressive strength of two glass ionomer cements, a conventional one (Vitro Fil ${ }^{\circledR}$ DFL) and a resin-modified material (Vitro Fil LC ${ }^{\circledR}$ - DFL), using two test specimen dimensions: One with $6 \mathrm{~mm}$ in height and $4 \mathrm{~mm}$ in diameter and the other with $12 \mathrm{~mm}$ in height and $6 \mathrm{~mm}$ in diameter, according to the ISO 7489:1986 specification and the ANSI/ADA Specification No. 66 for Dental Glass Ionomer Cement, respectively. Ten specimens were fabricated with each material and for each size, in a total of 40 specimens. They were stored in distilled water for 24 hours and then subjected to a compressive strength test in a universal testing machine (EMIC), at a crosshead speed of $0.5 \mathrm{~mm} / \mathrm{min}$. The data were statistically analyzed using the Kruskal-Wallis test $(5 \%)$. Mean compressive strength values $(\mathrm{MPa})$ were: $54.00 \pm 6.6$ and $105.10 \pm 17.3$ for the $12 \mathrm{~mm} \times 6 \mathrm{~mm}$ sample using Vitro Fil and Vitro Fil LC, respectively, and $46.00 \pm 3.8$ and $91.10 \pm 8.2$ for the $6 \mathrm{~mm} \times 4 \mathrm{~mm}$ sample using Vitro Fil and Vitro Fil LC, respectively. The resin-modified glass ionomer cement obtained the best results, irrespective of specimen dimensions. For both glass ionomer materials, the $12 \mathrm{~mm}$ x $6 \mathrm{~mm}$ matrix led to higher compressive strength results than the $6 \mathrm{~mm} \mathrm{x} 4 \mathrm{~mm}$ matrix. A higher variability in results was observed when the glass ionomer cements were used in the larger matrices.
\end{abstract}

Descriptors: Glass ionomer cements; Compressive strength; Materials testing.

Resumo: Este estudo teve como objetivo avaliar a resistência à compressão de dois cimentos de ionômero de vidro, um convencional (Vitro Fil ${ }^{\circledR}$ - DFL) e outro modificado por resina (Vitro Fil LC ${ }^{\circledast}$ - DFL), utilizando-se dois tamanhos de amostras: uma com $6 \mathrm{~mm}$ de altura e $4 \mathrm{~mm}$ de diâmetro e outra com $12 \mathrm{~mm}$ de altura e $6 \mathrm{~mm}$ de diâmetro, seguindo-se a especificação 7489:1986 da ISO e a especificação n. 66 da ANSI/ADA para Cimento Dental de Ionômero de Vidro, respectivamente. Foram confeccionados 10 corpos-de-prova (CP) de cada material para cada tamanho de amostra, totalizando $40 \mathrm{CP}$. Estes CP foram armazenados em água destilada e ensaiados 24 horas após a manipulação do material, sob uma carga de compressão em uma Máquina de Ensaio Universal (EMIC) a uma velocidade de $0,5 \mathrm{~mm} / \mathrm{min}$. Foi realizada a análise estatística para comparação dos resultados utilizando-se o teste Kruskal-Wallis (5\%). As médias dos testes de resistência à compressão (MPa) foram: 54,00 $\pm 6,6$ e 105,10 $\pm 17,3$ para a amostra de $12 \mathrm{~mm}$ x $6 \mathrm{~mm}$ utilizando-se Vitro Fil e Vitro Fil LC, respectivamente, e 46,00 \pm 3,8 e 91,10 \pm 8,2 para a amostra de $6 \mathrm{~mm} \times 4 \mathrm{~mm}$ utilizando-se Vitro Fil e Vitro Fil LC, respectivamente. O cimento de ionômero de vidro modificado por resina obteve melhores resultados independentemente do tamanho do corpo-de-prova. Para ambos os cimentos de ionômero de vidro, a matriz de $12 \mathrm{~mm}$ x $6 \mathrm{~mm}$ apresentou maiores valores de resistência que a matriz de $6 \mathrm{~mm} \times 4 \mathrm{~mm}$. Uma maior variabilidade nos resultados pôde ser observada quando os cimentos ionoméricos foram utilizados nas matrizes maiores.

Descritores: Cimentos de ionômeros de vidro; Força compressiva; Teste de materiais.
Received for publication on Oct 24, 2005 Sent for alterations on Mar 08, 2006 Accepted for publication on Dec 19, 2006 


\section{Introduction}

Glass ionomer cements were introduced in dental practice in the 70 s by Wilson, Kent ${ }^{15}$ (1972). Since then, several modifications have been introduced with the purpose of enhancing their mechanical properties and expanding their indications and clinical applications. ${ }^{7,11}$

For many years, glass ionomer cements were solely used for the restoration of anterior teeth, due to their poor mechanical strength. As improvements were introduced in their formulation, they started to be indicated for class I restorations of primary teeth. ${ }^{13}$ Nowadays, resin-modified glass ionomers and resin composites are commercially available, with superior values of mechanical strength when compared to conventional cements. ${ }^{2,4}$

Studies have been performed in an attempt to better understand their properties, and compressive strength testing is the most commonly employed method to evaluate the strength of these materials. To perform these studies, some researchers adopt standards and specifications for dental materials, instruments and dental equipments, and the ANSI/ADA Specification No. 66 1 (1987), which uses samples measuring $12 \mathrm{~mm}$ in height and $6 \mathrm{~mm}$ in diameter, is normally used. However, different specifications can be found, as in the study by Yap et al. ${ }^{17}$ (2002), and in that by Prosser et al. ${ }^{12}$ (1984), who evaluated the compressive strength of glass ionomer cements according to the British Standard ${ }^{5}$ (BS 6039:1981; $6 \mathrm{~mm}$ in height $\mathrm{x} 4 \mathrm{~mm}$ in diameter) or even according to another ISO specification ${ }^{8}(7489: 1986)$ that uses the same dimensions used by BS 6039:1981.

Williams, Billington ${ }^{14}(1989)$ analyzed the compressive strength of glass ionomer cements after 30 minutes, 1 hour and 24 hours following the specifications proposed by ISO 7489:1986 ${ }^{8}$, which considers specimens with $4 \mathrm{~mm}$ in diameter and $6 \mathrm{~mm}$ in height. Similarly, Williams, Billington ${ }^{14}$ (1989), Cattani-Lorente et al. ${ }^{3}$ (1994) and McComb et al. ${ }^{10}$ (1984) also followed ISO 7489:1986 specifications $^{8}$ for water-based dental cements. Gerdullo et al. ${ }^{7}$ (1995) and Drummond et al. ${ }^{6}$ (1988) differed from these authors regarding methodology when they used specimens with $12 \mathrm{~mm}$ in height and $6 \mathrm{~mm}$ in diameter to test the compressive strength of glass ionomer cements, thus following ANSI/ADA Specification No. $66^{1}$ for dental cements.

Among the details of both tests, it was observed that a 24-hour storage period has been the most widely chosen, since most of these materials reach their limit strength value within this period, which is recommended by the British Standard ${ }^{5}$ (BS 6039: 1981) and by the International Standard specified by $\operatorname{ISO}^{8}$ (7489: 1986).

Different methodologies can thus be employed to evaluate the compressive strength of glass ionomer cements, especially regarding standardization of specimen dimensions. However, doubts still remain as to whether any differences might be found in the results obtained when different specimen dimensions are used for testing materials with different formulations of conventional and resin-modified glass ionomer cements.

The purpose of this study was to evaluate the compressive strength of a conventional and a resinmodified glass ionomer cement using two different specimen dimensions established according to ISO and ANSI/ADA specifications.

\section{Material and Methods}

Two glass ionomer cements were employed in this study, a conventional one (Vitro Fil - DFL Ind./Rio de Janeiro, RJ, Brazil) and a resin-modified material (Vitro Fil - DFL Ind./Rio de Janeiro, RJ, Brazil), using two specimen dimensions: $12 \mathrm{~mm}$ x $6 \mathrm{~mm}$ and $6 \mathrm{~mm} \times 4 \mathrm{~mm}$, according to ANSI/ADA Specification No. $66^{1}$ for dental cements and ISO 7489:1986 ${ }^{8}$ (ISO 9917:1991 reference) specifications for waterbased dental cements, respectively. Table 1 shows the manufacturers, batch numbers and composition of the materials used in this study.

Two mountable metallic matrices were made and identified as matrix A $(12 \mathrm{~mm}$ in height and $6 \mathrm{~mm}$ in diameter) and matrix $B(6 \mathrm{~mm}$ in height and $4 \mathrm{~mm}$ in diameter) (Figure 1).

Ten specimens were fabricated for each group, in a total of 40 specimens. The materials were manipulated according to the powder/liquid ratio recommended by the manufacturer. In order to obtain a smooth and shiny glass ionomer cement, powder and liquid were dropped and manipulated over a pol- 
ished, thick and slightly refrigerated glass slab, since the mixing sheets supplied by the manufacturer were too small for preparation of the amount of material required to fill the matrices. The conventional glass ionomer cement was inserted in only one increment. Three measuring spoons of powder and 3 drops of liquid were necessary to fill the $12 \mathrm{~mm}$ x $6 \mathrm{~mm}$ matrix and 2 measuring spoons of powder and 2 drops of liquid were required to fill the $6 \mathrm{~mm} \times 4 \mathrm{~mm}$ matrix. The resin-modified glass ionomer cement was inserted in 2-mm increments and, for each increment, 1 portion of the material was used. A plastic spatula (Jon Produtos Odontológicos, São Paulo, SP, Brazil) was used to avoid contamination with metallic particles. The metallic matrices were previously isolated with Vaseline (Fórmula e Ação, São Paulo, SP, Brazil) and protected at the bottom surface using a mylar strip (TDV Dental, Pomerode, SC, Brazil). The materials were slowly inserted through matrix openings using a Centrix type syringe (DFL Ind., Rio

Table 1 - Materials, manufacturers, batch numbers and composition.

\begin{tabular}{l|l|l}
\hline \multirow{2}{*}{$\begin{array}{l}\text { Materials } \\
\text { (Manufacturers) }\end{array}$} & \multicolumn{2}{|c}{ Composition } \\
\cline { 2 - 3 } $\begin{array}{l}\text { Vitro Fil }{ }^{\circledR} \text { (DFL) } \\
\text { Batch \#: }\end{array}$ & $\begin{array}{l}\text { Strontium aluminum } \\
\text { silicate, dehydrated } \\
\text { polyacrylic acid and } \\
\text { iron oxide }\end{array}$ & $\begin{array}{l}\text { Polyacrylic acid, } \\
\text { tartaric acid and } \\
\text { distilled water }\end{array}$ \\
\hline $\begin{array}{l}\text { Vitro Fil LC } \\
\text { Batch \#: }\end{array}$ & $\begin{array}{l}\text { Strontium aluminum } \\
\text { silicate, excipients, } \\
\text { activators and iron } \\
\text { oxide } 1094\end{array}$ & $\begin{array}{l}\text { 2-hydroxyethyl } \\
\text { methacrylate, } \\
\text { polyacrylic and } \\
\text { tartaric acid solutions, } \\
\text { benzoyl peroxide and } \\
\text { camphorquinone }\end{array}$ \\
\hline
\end{tabular}

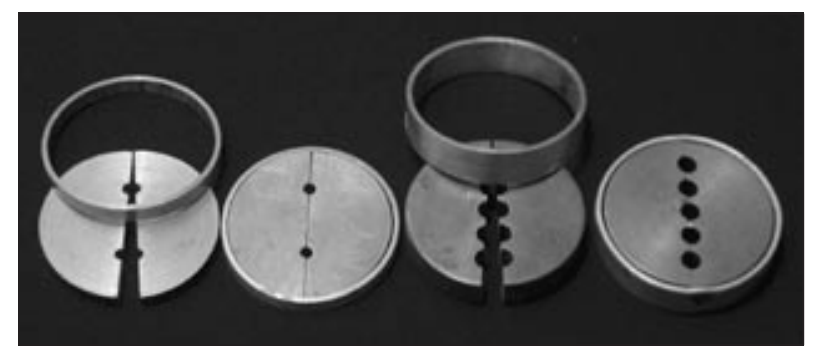

Figure 1 - Mountable metallic matrices used in the study. On the left side is the $6 \mathrm{~mm} \times 4 \mathrm{~mm}$ matrix, dismounted and mounted, and on the right side is the $12 \mathrm{~mm} \times 6 \mathrm{~mm}$ matrix, dismounted and mounted. de Janeiro, RJ, Brazil). Another mylar strip (TDV) was placed on the upper surface followed by a $2-\mathrm{mm}$ thick glass slab manually pressured to obtain a regular material surface. The resin-modified glass ionomer material (Vitro Fill LC) was inserted in 2-mm layers, and each one was light-cured for $40 \mathrm{~s}$ using a quartz-tungsten-halogen unit (Optilux 400 - Kerr Dental, Orange, CA, USA) with a light intensity of $500 \mathrm{~mW} / \mathrm{cm}^{2}$. For the resin-modified glass ionomer, specimens were fabricated one at a time. The specimens were visually analyzed and, when voids or irregularities were detected, they were discarded.

After the specimens were left undisturbed for $30 \mathrm{~min}$, they were stored in distilled water for 24 hours, after which they were subjected to compressive strength testing in a universal testing machine (EMIC, São José dos Pinhais, PR, Brazil) using a claw with $2 \mathrm{~cm}$ in diameter, under a crosshead speed of $0.5 \mathrm{~mm} / \mathrm{min}$ until specimen fracture. The specimens were measured using a digital caliper (Mitutoyo Corp., Aurora, IL, USA) before being loaded.

The data were analyzed by the Kruskal-Wallis test $(5 \%)$ using the statistical GMC Basic Software, Version 8.1 (Geraldo Maias Campos, Ribeirão Preto, SP, Brazil), which performed comparisons of all the studied means.

\section{Results}

The compressive strength results are shown in Table 2. Statistically significant differences were observed when the conventional and resin-modified glass ionomers were compared: for both matrices, higher compressive strength values were found for the latter material. Differences were also observed

Table 2 - Mean compressive strength values (MPa), standard deviations, and coefficient of variation obtained for the glass ionomer cements using two specimen dimensions.

\begin{tabular}{|c|c|c|}
\hline Matrix & Vitro Fil ${ }^{\circledast}(\mathrm{DFL})$ & Vitro Fil LC ${ }^{\circledR}$ (DFL) \\
\hline $\mathrm{A}(12 \mathrm{~mm} \times 6 \mathrm{~mm})$ & $\begin{array}{c}54.00 \pm 6.56 \\
(12.1)^{\mathrm{Aa}}\end{array}$ & $\begin{array}{c}105.10 \pm 17.29 \\
(16.5)^{B a}\end{array}$ \\
\hline$B(6 \mathrm{~mm} \times 4 \mathrm{~mm})$ & $\begin{array}{c}46.00 \pm 3.80 \\
(8.3)^{\mathrm{Ab}}\end{array}$ & $\begin{array}{c}91.10 \pm 8.17 \\
(9.0)^{\mathrm{Bb}}\end{array}$ \\
\hline
\end{tabular}

Different superscript uppercase letters represent horizontal differences. Different superscript lowercase letters represent vertical differences $(p<0.05)$. 
$(\mathrm{p}<0.05)$ between the samples with different dimensions: the largest specimens $(12 \mathrm{~mm}$ x $6 \mathrm{~mm})$ presented the greatest values, irrespective of the glass ionomer material used.

\section{Discussion}

There are several clinical indications for the use of glass ionomer cements, such as bonding to the dental substrate and fluoride release. However, some of these indications are limited by their mechanical strength. Several ionomer materials have been developed in an attempt to enhance their mechanical properties, a fact that justifies the constant research effort that has been made to assess the alleged improvements.

In this study, the resin-modified glass ionomer cement presented higher strength values than the conventional material, irrespective of the matrix dimensions employed for specimen fabrication. Probably, this is due to the inclusion of resinous polymers that present higher mechanical strength. These results were already expected, as observed in other studies $^{16}$ and mentioned in the classic dental materials literature. ${ }^{2}$

Variability was observed in the compressive strength results observed for the two glass ionomer cements, but it was more evident for the resin-modified glass ionomer as the coefficient of variation was higher in this material. McCabe et al. ${ }^{9}$ (1990) evaluated the standardization of mechanical tests for glass ionomer cements and reported difficulty in performing compressive strength testing of these materials. They concluded that standardization is difficult to achieve because of the great variability in the results. Variation of results can be attributed to difficulty in manipulating large amounts of material and to specimen dimensions.

In the present study, the specimens with larger dimensions (12 mm x $6 \mathrm{~mm}$ ) presented higher compressive strength values and also greater variability in the results. This fact demonstrates that one should not only compare absolute values when using specimens with different standardized dimensions, as specified by ISO 7489:1986 and ANSI/ADA Specification No. 66 1 . However, when specimens prepared according to each of the dimensions are individually analyzed, it can be observed that the differences in the results are proportionally similar, despite the different absolute values. The specimens of both conventional and resin-modified glass ionomer cements with smaller dimensions presented compressive strength values approximately $85 \%$ of those of the specimens with larger dimensions. Hence, both dimensions, $12 \mathrm{~mm} \mathrm{x}$ $6 \mathrm{~mm}$ and $6 \mathrm{~mm} \times 4 \mathrm{~mm}$, can be used to compare the compressive strength of these materials.

Glass ionomer cements are very technique- and methodology-sensitive, and are even subject to failures during manipulation, a very important aspect when materials that require manual mixing are tested. For these reasons, the authors of this study suggest the use of smaller specimen dimensions $(6 \mathrm{~mm} \times 4 \mathrm{~mm})$ to investigate mechanical properties of glass ionomer cements, according to ISO 7489:1986 specifications ${ }^{8}$. The objective is to reduce the variability that may result when large amounts of material are manipulated.

Another aspect that must be emphasized is that resinous glass ionomer materials are light-cured and therefore should not be placed in increments larger than $2 \mathrm{~mm}$, as recommended by manufacturers, to allow adequate initial cure. Hence, when smaller matrices are used, the necessity of manipulating several increments of material is reduced, which may, in turn, result in a lower number of voids and internal failures and, consequently, in better standardization of the results.

Further research is required to confirm our findings, since few studies can be found in the literature regarding the influence of different methods on the testing procedures of dental materials.

\section{Conclusions}

Considering the results obtained in this study, it can be concluded that:

- The resin-modified glass ionomer cement and larger specimens presented higher compressive strength values.

- A higher variability in results was observed when the glass ionomer cements were used in larger matrices.

\section{Acknowledgements}

To DFL for supplying the materials tested in this study. 


\section{References}

1. ANSI/ADA Specification No. 66 for Dental Glass Ionomer Cement (1987).

2. Anusavice KJ. Phillips' science of dental materials. $10^{\text {th }}$ ed. Philadelphia: Saunders; 1996.

3. Cattani-Lorente MA, Godin C, Meyer JM. Mechanical behavior of glass ionomer cements affected by long-term storage in water. Dent Mater. 1994;10(1):37-44.

4. Craig R, Powers J. Materiais dentários restauradores. $11^{\mathrm{a}}$ ed. São Paulo: Santos; 2004.

5. Dental Standards Committee, BS 6039:1981. British Standard Specification for Dental Glass Ionomer Cements, British Standard Institution; 1981.

6. Drummond JL, Lenke JW, Randolph RG. Compressive strength comparison and crystal morphology of dental cements. Dent Mater. 1988;4(1):38-40.

7. Gerdullo ML, Nakamura SCB, Suga RS, Navarro MFL. Resistência à compressão e à tração diametral de cimentos de ionômero de vidro indicados para cimentação. Rev Odontol Univ São Paulo. 1995;9(1):17-22.

8. International Organization for Standardization. ISO 7489. Dental glass polyalkenoate cements. Genebra; 1986.

9. McCabe JF, Watts DC, Wilson HJ, Worthington HV. An investigation of test-house variability in the mechanical testing of dental materials and the statistical treatment of results. J Dent. 1990;18(2):90-7.
10. McComb D, Sirisko R, Brown J. Comparison of physical properties of commercial glass ionomer luting cements. J Can Dent Assoc. 1984;50(9):699-701.

11. Pimenta LAF, Lovadino JR, Giannini M. Resistência ao Cisalhamento de Dois Materiais Híbridos em Esmalte. Rev Assoc Paul Cir Dent. 1997;51(6):587-90.

12. Prosser HJ, Powis DR, Brant P, Wilson AD. Characterization of glass-ionomer cements. 7. The physical properties of current materials. J Dent. 1984;12(3):231-40.

13. Williams JA, Billington RW. Changes in compressive strength of glass ionomer restorative materials with respect to time periods of 24 h to 4 months. J Oral Rehabil. 1991;18(2):1638 .

14. Williams JA, Billington RW. Increase in compressive strength of glass ionomer restorative materials with respect to time: a guide to their suitability for use in posterior primary dentition. J Oral Rehabil. 1989;16(5):475-9.

15. Wilson AD, Kent BE. A new translucent cement for dentistry. The glass ionomer cement. Br Dent J. 1972;132(4):133-5.

16. Xie D, Brantley WA, Culbertson BM, Wang G. Mechanical properties and microstructures of glass-ionomer cements. Dent Mater. 2000;16(2):129-38.

17. Yap AUJ, Cheang PHN, Chay PL. Mechanical properties of two restorative reinforced glass-ionomer cements. J Oral Rehabil. 2002;29(7):682-8. 